\title{
Źródła do działalności edukacyjnej konwiktu szlacheckiego w Tarnopolu
}

\author{
Sources for Educational Activities \\ of the Secondary Boarding School in Tarnopol
}

\begin{abstract}
ABSTRAKT
W tworzeniu monografii instytucji edukacyjnej należy odwołać się do źródeł rękopiśmiennych zwiq̨zanych z działalnościq zakonu jezuitów i tych bezpośrednio odnoszqcych się do konwiktu w Tarnopolu. Kluczowym materiałem źródłowym będq dekrety określajqce program i metody nauczania, spisy profesorów i uczniów, instrukcje dla nauczycieli i wychowawców pracujacych w konwikcie, reguły szkolne dla konwiktu w Tarnopolu, programy muzyczne i teatralne.

Ważnym materiałem będq wydawnictwa źródłowe, należy tu uwzględnić przede wszystkim: ustawy, rozporządzenia i dekrety władz zaborczych dotyczqce prowadzenia, funkcjonowania, organizacji szkół w cesarstwie austriackim. Cennym materiałem źródłowym będq również różnego typu wydawnictwa okolicznościowe czy wspomnienia uczniów. Znaczqca pomoca w określeniu działalności edukacyjnej konwiktu będa opracowania powstałe wcześniej, a dotyczqce bezpośrednio szkoły, jak i działalności zakonu jezuitów tamtego okresu.

Przywołane w artykule źródła rękopiśmienne, drukowane i wspomniane opracowania nie wyczerpuja $w$ pełni podiętego tematu. Należy zaznaczyć, że nie ma pełnych źródeł dotyczqcych konwiktu

SLOWA KLUCZOWE źródła rękopiśmienne, źródła drukowane, edukacja, konwikt szlachecki w Tarnopolu, Galicja.

KEY WORDS

manuscript sources, printed sources, education, gentry secondary boarding school (konwikt szlachecki) in Tarnopol, Galicia

SPI Vol. 19, 2016/3

ISSN 2450-5358

e-ISSN 2450-5366 DOI: 10.12775/SPI.2016.3.011 Raporty z badań
\end{abstract}


tarnopolskiego. Mam nadzieję, że przedstawiony materiał źródłowy pozwoli na odtworzenie działalności edukacyinej tego konwiktu, niewatpliwie zasługujqacego na przypomnienie, chociażby ze względu na jego znaczenie w kształceniu polskiej młodzieży w dobie zaborów.

\section{ABSTRACT}

When creating a monograph of an educational institution, it is necessary to refer to manuscript sources connected with activities of the Jesuit Order as well as to those directly relating to the boarding school in Tarnopol. Among essential source materials there will be decrees specifying the curriculum and teaching methods, lists of teachers and students, instructions for teachers and educators working in the school, the school code of conduct, programs of music and theatre performances.

Moreover, publications will also serve as a significant source in the study, especially laws, regulations and decrees of Partition authorities referring to the management, functioning and organisation of schools in the Austrian Empire. Another valuable source material will also be commemorative publications and memoirs of alumni. The study material which was created earlier, and directly refers to the school as well as to the activities of the Jesuit Order of the period will be considerably helpful in establishing the educational activities of the secondary boarding school.

The manuscript and printed sources mentioned in the article are not sufficient enough to exhaust the undertaken subject. It needs to be emphasised that there are no complete sources referring to the Secondary Boarding School in Tarnopol. I do hope that the remaining source material will allow to reconstruct the educational activity of the secondary boarding school in Tarnopol, which, undoubtedly, deserves recollection, if only owing to its importance in the education of the Polish youth in the period of the Partitions of Poland.

\section{Wprowadzenie}

W 1820 roku, po ponad 40 latach nieobecności, jezuici wrócili na południowo-wschodnie ziemie dawnej Rzeczypospolitej, do ówczesnej Galicji. Powrót jezuitów związany był z decyzją Aleksandra I o wygnaniu zakonników z terytorium Imperium Rosyjskiego, gdzie 
pozostali po ogłoszeniu breve kasacyjnego w 1773 roku. Osiedleniu się jezuitów w Galicji sprzyjały okoliczności, bowiem na terenach archidiecezji lwowskiej i diecezji przemyskiej brakowało zarówno księży do posługi duszpasterskiej, jak i do pracy wychowawczej z młodzieżąa ${ }^{1} \mathrm{Z}$ tego też powodu cesarz Franciszek I zdecydował o pozostawieniu jezuitów w Galicji. Pierwotnie postanowiono, że zakonnicy mieliby osiedlić się w Tarnowie i tam zająć się edukacją młodzieży. Jednak decyzją cesarską z 20 sierpnia 1820 roku jezuici mieli zorganizować i poprowadzić gimnazjum wraz z konwiktem w Tarnopolu. Decyzją władz austriackich na swoją siedzibę otrzymali klasztor i kościół podominikański².

\section{Jezuici w Tarnopolu w latach 1820-1886}

Działalność edukacyjną jezuitów w Tarnopolu należy podzielić na dwa okresy: pierwszy - od przybycia jezuitów do Galicji w 1820 roku aż do Wiosny Ludów i decyzji władz austriackich o zamknięciu szkoły; drugi - od wznowienia konwiktu w 1856 roku aż do przeniesienia konwiktorów do nowo utworzonej szkoły w Chyrowie.

Jezuici, posłuszni postanowieniu cesarskiemu, 6 listopada 1820 roku otwarli w Tarnopolu pierwszą szkołę publiczną. Już 1 października 1821 roku w Tarnopolu utworzono gimnazjum. Po trzech latach, w 1823 roku, uruchomiono studia filozoficzne dla studentów świeckich i kleryków jezuickich. „We wrześniu 1821 jezuici otwarli konwikt, początkowo jako prywatny dom wychowawczy pod kierunkiem Jana Oeillarda. (...) Konwiktorzy pochodzili z całej monarchii austriackiej. Uczęszczali na wykłady do jezuickich szkół publicznych oraz posiadali zapewnione dodatkowe wykształcenie i wychowanie"3. W przeciągu dwóch lat (1822-1823) zbudowano dwupiętrowy

1 B. Kumor, Powrót jezuitów do Galicji, „Folia Historica Cracoviensia” 1994, nr 2, s. 75; A. Demkowicz, Wypędzenie jezuitów z Imperium Rosyjskiego na podstawie fragmentów „Wygnańca z Biatej Rusi” Jana Galicza, „Tematy i Konteksty" 2012, nr 2(7), s. 54.

2 Tamże, s. 79; S. Załęski, Jezuici w Polsce, t. V, cz. II, Jezuici w Polsce porozbiorowej 1820-1905, Kraków 1906, s. 535.

3 Encyklopedia wiedzy o jezuitach na ziemiach Polski i Litwy, 1564-1995, opracował L. Grzebień przy współpracy zespołu jezuitów, Kraków 1996, http://jezuici.krakow.pl/cgi-bin/rjbo?b=enc\&q=TARNOPOL\&f=1 [dostęp: 23.01.2016]. 
gmach konwiktu z kilkudziesięcioma pokojami dla przyszłych uczniów. Jezuici postanowili, że naukę rozpoczną uczniowie w czterech niższych klasach gimnazjum, a następnie zdecydowali o otwarciu czterech wyższych klas gimnazjalnych z kursem przygotowawczym. W latach 1825-1826 zbudowano dostosowany do potrzeb szkoły jezuickiej nowy budynek szkolny. W 1836 roku miało miejsce istotne wydarzenie - cesarz wyraził zgodę, aby prowadzone w Tarnopolu studia filozoficzne zostały dostosowane do jezuickiej Ratio Studiorum. Liczba uczniów w szkołach jezuickich wzrosła od $394 \mathrm{w}$ roku 1824 do około 500 uczniów w 1836 roku. „Wiosna Ludów” w Galicji nie sprzyjała prowadzeniu szkół i decyzją cesarską, w czerwcu 1848 roku, jezuici zmuszeni zostali do zamknięcia swoich szkół w Galicji.

W Galicji ponownie jezuici mogli wznowić działalność w 1852 roku. Decyzja o przywróceniu jezuitom na własność konwiktu w Tarnopolu zapadła dopiero 13 czerwca 1853 roku, jednakże nie udało się im uzyskać praw państwowych dla otwartego ponownie w 1856 roku konwiktu. Wobec powyższego podjęto decyzję o prowadzeniu konwiktu prywatnego ${ }^{5}$, w którym młodzież będzie uczyła się przedmiotów w zakresie szkoły średniej, ale już bez studiów filozoficznych. W latach siedemdziesiątych XIX wieku poszerzono i zmodernizowano budynek konwiktu. W Tarnopolu, w miejsce dawnego jezuickiego gimnazjum, utworzono gimnazjum państwowe. Jezuici zadbali o to, aby ich wychowankowie mieli możliwość uzyskania tam matury państwowej. Zakonnicy podjęli rozmowy z dominikanami o odkupieniu zajmowanych dotąd budynków. Po nieudanych rozmowach powzięli decyzję o przeniesieniu konwiktu z Tarnopola do Chyrowa. W 1886 roku w konwikcie w Tarnopolu pozostali uczniowie klas najwyższych (było ich 29, potem 22). Ostatecznie jezuici zamknęli konwikt w Tarnopolu w 1887 roku'

4 L. Grzebień, B. Topij-Stempińska, Konwikt szlachecki w Tarnopolu 1856-1886. Stownik wychowanków, Kraków 2016, s. 7.

5 J. Niemiec, Z dziejów szkolnictwa jezuickiego na ziemiach Rzeczypospolitej w latach 1564-1886, „Resovia Sacra. Studia Teologiczno-Filozoficzne Diecezji Rzeszowskiej 5”1998, s. 282-283.

6 L. Grzebień, B. Topij-Stempińska, Konwikt szlachecki w Tarnopolu 1856-1886. Stownik wychowanków, dz. cyt., s. 8-9; S. Załęski, Jezuici w Polsce, t. V, cz. II, Jezuici w Polsce porozbiorowej 1820-1905, dz. cyt., s. 924. 
W tym miejscu należy zapytać o źródła informacji nie tylko o przedstawionych powyżej faktach, ale też w jakich źródłach znajdzie badacz informacje dotyczące podejmowanej przez jezuitów w ciągu XIX wieku działalności edukacyjnej w Tarnopolu, czy też jakie źródła zachowały się do czasów współczesnych, z których badacz może czerpać informacje o działalności konwiktu w Tarnopolu.

\section{2. Źródła historyczne w badaniach instytucii oświatowych w Galicii}

W podejmowanych badaniach $\mathrm{z}$ zakresu historii oświaty i edukacji istotną rolę odgrywają źródła historyczne, podobnie jak we wszystkich rodzajach badań podejmowanych przez historyków. Nawet jeżeli nadal brak wspólnego stanowiska w rozumieniu istoty i roli, jaką pełnią źródła w procesie badawczym historyków, a nawet w przypadku wielu rozbieżności w ujęciach definicji czy typologii, to niewątpliwie materiał źródłowy jest niezbędny w procesie badawczym podejmowanym przez historyków ${ }^{7}$. Zatem można przyjąć za Jerzym Topolskim, że źródłem ,jest wszystko to, skąd możemy czer-

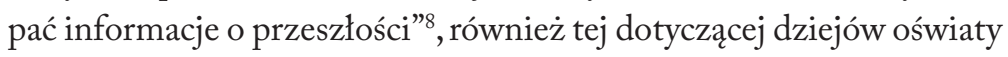
i myśli pedagogicznej. Odpowiadając na postawione powyżej pytania,

7 Znaczenie i rolę źródeł historycznych w badaniach podejmowali m.in.: M. Handelsman, Historyka: zasady metodologii i teorii poznania historycznego, Warszawa 1928; S. Kościałkowski, Historyka. Wstęp do studiów historycznych, Londyn 1954; G. Labuda, Próba nowej systematyki i nowej interpretacji źródet historycznych, „Studia Źródłoznawcze” 1957, nr 1, s. 3-52; B. Kürbis, Metody źódtoznawcze wczoraj i dzis, „Studia Źródłoznawcze” 1979, nr 24, s. 83-96; J. Topolski, Metodologia historii, Warszawa 1984; J. Topolski, Jak sie pisze i rozumie historie, Warszawa 1998; Z. Wojtkowiak, Nauki pomocnicze historii najnowszej. Źródtoznawstwo. Źródta Narracyjne, częś́ I: Pamiętnik. Tekst literacki, Poznań 2001.

Szerzej na temat definicji, różnic, rozbieżności w rozumieniu i podejściu metodologicznym do kwestii źródeł: J. Topolski, Czy historyk ma dostęp do przesztej rzeczywistości. Problem źródet historycznych, w: Historia: o jeden swiat za daleko?, wstęp, przekład i opracowanie E. Domańska, Poznań 1997; A. Radomski, Czy jest możliwa historyczna interpretacja źródet, https://www. academia.edu/4167792/Czy_jest_mo\%C5\%BCliwa_historyczna_interpretacja_tekst $\% \mathrm{C} 3 \% \mathrm{~B} 3 \mathrm{w} \_\% \mathrm{C} 5 \% \mathrm{BAr} \% \mathrm{C} 3 \% \mathrm{~B} 3 \mathrm{~d} \% \mathrm{C} 5 \% 82$ owych [dostęp: 4.03.2016]; również M. Moskalewicz, Refleksja nad źródtem a problem źródtowości, w: Przez źródto do przesztości: materiaty z II Sesji naukorvej doktorantów Wydziatu Historycznego UAM, Poznañ, 12-15 kwietnia 2008 roku, red. I. Grzelczak-Miłoś, M. Praczyk, K. Wiśniewski, Poznań 2012.

8 J. Topolski, Wprowadzenie do historii, Poznań 2009, s. 35. 
należy się zastanowić, z jakich źródeł korzysta zazwyczaj historyk wychowania badający dzieje instytucji oświatowych w Galicji.

Zdaniem Andrzeja Meissnera, w badaniach dotyczących dziejów oświaty w Galicji współczesny badacz może korzystać z materiału archiwalnego (rękopiśmiennego i drukowanego) zgromadzonego w archiwach we Lwowie i Wiedniu oraz w innych archiwach zagranicznych i polskich ${ }^{9}$. Inicjując proces badawczy, badacz w pierwszej kolejności poszukuje informacji zgromadzonych w pozostawionych źródłach tzw. pisanych. Do tej grupy źródeł zaliczyć możemy zarówno materiały zachowane w rękopisach, jak i źródła drukowane. A. Meissner przyjął, za Stanisławem Kościałkowskim, że źródła pisane można podzielić na dokumentalne, narracyjne i epistolarne ${ }^{10}$. Przyjmując ten podział, należy odwołać się do źródeł dokumentalnych o charakterze normatywnym (akty i normy prawne: ustawy, rozporządzenia, przepisy, zarządzenia, statuty, regulaminy). Inaczej ujmując, chodzi o wszystkie dokumenty „,regulujące działalność państwa w dziedzinie oświaty, kształcenia i wychowania oraz stosunki prawne, jakie w tym zakresie powstają" ${ }^{11}$. W źródłach tego typu znajdzie badacz informacje dotyczące prawnych podstaw funkcjonowania szkoły, m.in. władz szkolnych, zasad powołania i odwołania instytucji oświatowych. Ponadto do tej grupy materiału źródłowego zaliczyć należy plany, programy nauczania, statuty, regulaminy oraz wszystkie dokumenty prawne wydawane przez właściwy resort czy samą placówkę oświatową. Dzięki takim dokumentom możliwe jest poznanie oficjalnej strony życia szkoły - zasad jej funkcjonowania, zewnętrznych i wewnętrznych praw regulujących życie szkoły, itp. ${ }^{12}$.

9 A. Meissner, Źródta drukowane do dziejórw oświaty, w: Źródta w badaniach naukowych historii edukacji, red. W. Szulakiewicz, Torun 2003, s. 44.

10 Tamże. Taką samą klasyfikację źródeł, omawiając źródła do dziejów szkolnictwa w Galicji doby autonomicznej, przyjęła Joanna Falkowska: J. Falkowska, Dzienniki urzędowe c.k. Rady Szkolnej Krajowej jako źródto do dziejórw oświaty w Galicji, w: Badania historyczne w pedagogice. Konteksty źródtowe, red. W. Szulakiewicz, Torun 2015, s. 77.

11 A. Meissner, Źródta drukowane do dziejów oświaty, dz. cyt., s. 45; zob. J. Homplewicz, Zagadnienia ustawodawstwa szkolnego. Zarys problematyki polskiego prawa szkolnego, Katowice 1973.

12 Szerzej na temat istotnych dokumentów prawnych obowiązujących w Galicji w: A. Meissner, Źródta drukowane do dziejów oświaty, dz. cyt., s. 46-48; również A. Jagusztyn, Źródto drukowane do dziejów oświaty w Galicji w wybranych bibliotekach $i$ archiwach Polski potudniowo-wschodniej, w: $Z$ dziejów 
Ponadto, jak zaznacza A. Meissner, istotnym źródłem są różnorodne materiały o charakterze statystycznym. Warto przywołać tu tzw. schematyzmy ${ }^{13}$. Ich podstawowym zadaniem było przekazanie informacji m.in. o personalnej obsadzie najważniejszych stanowisk w cesarstwie austriackim, jednakże zawierają także informacje istotne dla badacza dziejów instytucji oświatowych, np. dane personalne władz szkolnych.

Źródła narracyjne, takie jak: kroniki, roczniki, wspomnienia, dzienniki, ale również sprawozdania szkolne, czasopisma, dzieła pedagogiczne itp., ,zawierają nie tylko określone informacje o przeszłości, lecz także subiektywne opinie (beliefs) nadawców. Są one nasycone interpretacjami, tworząc określone całości retoryczne, innymi słowy są one konstrukcjami narracyjnymi" ${ }^{14}$. Zatem są to źródła, dzięki którym otrzymujemy informacje od świadków wydarzeń, należy jednak pamiętać, że są to fakty przekazane przez osoby trzecie. Niemniej ten rodzaj źródeł pozwalała na dopełnienie oficjalnego obrazu szkoły o materiał związany bezpośrednio np. z działalnością: naukową, dydaktyczną, wychowawczą badanych instytucji oświatowych. Ponadto źródła narracyjne zaliczane do ego-dokumentów często są jedynym materiałem źródłowym, dzięki któremu „uzyskujemy informacje niezbędne dla stworzenia obrazu przeszłości, takie jak klimat duchowy okresu historycznego, który nie jest możliwy do odtworzenia na podstawie innych dokumentów"15. W badaniach dziejów instytucji na uwagę zasługują również wspominane już wyżej źródła epistolarne. „Trudno bowiem wyobrazić sobie dzisiaj - jak zaznacza Władysława Szulakiewicz - badania naukowe bez wykorzystania źródła, jakim jest korespondencja”" ${ }^{16}$. Ten rodzaj źródeł często pozwala badaczowi

oświaty w Galicji: materiaty z sesji naukowej zorganizowanej w Eańcucie w dniach 23-25 października 1986 roku na temat „Stan i potrzeby badań nad dziejami oświaty w Galicji”, red. A. Meissner, Rzeszów 1989, s. 297-310.

13 Ten rodzaj źródeł szerzej omówiła Henryka Kramarz.

14 J. Topolski, Czy historyk ma dostęp do przesztej rzeczywistości? Problem źródet historycznych, dz. cyt., s. 64.

15 W. Szulakiewicz, Ego-dokumenty $i$ ich znaczenie w badaniach naukowych, „Przegląd Badań Edukacyjnych” 2013, nr 16, s. 79.

16 W. Szulakiewicz, Korespondencja w badaniach historii edukacji i nauki, w: Badania historyczne w pedagogice. Konteksty źródtowe, red. W. Szulakiewicz, Toruń 2015, s. 25; Zob. również: T.J. Lis, Źródta narracyjne do dziejów Polonii w Bośni i Hercegowinie w okresie austro-węgierskim, „Balcanica Posnaniensia” 2015 , nr 22/2, s. 75-89. 
przedstawić zagadnienie, które dopiero w uzupełnieniu o informacje zawarte w korespondencji staje się „czytelne” i zrozumiałe, także dla czytelnika.

W badaniach dotyczących działalności edukacyjnej instytucji oświatowej warto uwzględnić również druki ulotne, wydawnictwa okolicznościowe, „projekty reform, publikacje dla rodziców, (...), odczyty, katalogi, (...) dzieła literackie" ${ }^{17}$. Należy pamiętać, że ta ostatnia grupa źródeł ma zazwyczaj charakter przyczynkarski, uzupełniający, pozwala jednak na poszerzenie pól badawczych, a tym samym ukazanie (na ile to możliwe) obiektywnego obrazu instytucji edukacyjnej.

Opracowując monografię instytucji edukacyjnej, należy w miarę możliwości uwzględnić wszystkie wymienione typy źródeł ${ }^{18}$, bowiem jeden rodzaj źródła nie pozwoli badaczowi na odtworzenie dziejów instytucji.

\section{Materiał źródłowy do działalności edukacyjnej konwiktu szlacheckiego w Tarnopolu}

Przystępując do przygotowania monografii na temat działalności edukacyjnej konwiktu w Tarnopolu, badacz powinien mieć na uwadze pola zainteresowań badawczych, które wskazują ,jednoznacznie na zakres poszukiwań źródłowych" ${ }^{19}$. W przypadku konwiktu w Tarnopolu źródła archiwalne znajduje się przede wszystkim w Archiwum Prowincji Południowej Towarzystwa Jezusowego w Krakowie. Zgromadzone w Archiwum dokumenty można podzielić według przyjętej powyżej typologii. Znajdują się tam zarówno źródła, które zaliczamy do tych o charakterze normatywnym, narracyjnym, jak i epistolarnym.

17 A. Meissner, Źródta drukowane do dziejórw oświaty, dz. cyt., s. 73.

18 Należy wziąć pod uwagę wszystkie dostępne materiały źródłowe, również takie, które w tym opracowaniu nie zostały uwzględnione, np. ikonograficzne, a które jednak w podjętym procesie badawczym mogą ukazać istotne fakty związane z działalnością instytucji edukacyjnej.

19 G. Michalski, Zakres poszukiwań źródtowych w badaniach historyczno-pedagogicznych stowarzyszeñ, w: Źródta w badaniach naukowych historii edukacji, red. W. Szulakiewicz, Toruń 2003, s. 153. 
Badając działalność edukacyjną szkoły prowadzonej przez zakon należy poddać analizie źródła odnoszące się bezpośrednio do działalności zakonu - zbiory dokumentów dotyczących prowincji mogą zawierać pojedyncze dokumenty odnoszące się wprost do (lub zawierające treści dotyczące) konwiktu w Tarnopolu. W Archiwum znajdują się m.in. zbiory dokumentów dotyczących Prowincji Galicyjskiej. Zaliczyć je możemy głównie do źródeł narracyjnych i epistolarnych, np. projekty programów, listy prowincjała do władz świeckich i kościelnych, ale znajdują się tam także źródła normatywne, jak np. regulaminy konwiktu.

Najistotniejsze będą jednak Akta konwiktu tarnopolskiego z lat 1824-1920. Składa się nań m.in.: korespondencja władz zakonu, broszury, projekty programów. Wśród wielu dokumentów znajdują się: Rozkład tygodniowy godzin nauki w konwikcie w Tarnopolu, Plan naukowy dla 4-klasowej szkoty gtównej w Tarnopolu, Programm des k.k. Obergymnasium in Tarnopol für das Schuljarhr $1856^{20}$. Wprawdzie zachowały się nieliczne dokumenty, ale być może pozwolą one na poznanie m.in. obowiązującej w szkole „siatki godzin” oraz treści i zakresu wykładanych przedmiotów, np. przez odwołanie się do prawa szkolnego obowiązującego w całym cesarstwie austriackim. Należy mieć nadzieję, że zgromadzone plany dnia, programy kształcenia, sprawozdania $\mathrm{z}$ postępów w nauce szkolnej, umożliwią poznanie szkoły tarnopolskiej z tej oficjalnej strony. Ponadto odpowiedzi na pytanie o obowiązujące w konwikcie w Tarnopolu normy i zasady znajdą się zapewne w zachowanych regulaminach.

Natomiast inne dokumenty dotyczące spraw związanych z działalnością konwiktu, np. zachowana korespondencja prowincjała $\mathrm{z}$ urzędującymi starostami, właściwym ministerstwem do spraw szkolnictwa, prawdopodobnie pozwoli prześledzić i odtworzyć m.in. długoletnie zmagania zmierzające do uzyskania praw i pozwolenia na prowadzenie szkoły zgodnie z zasadami zakonu. Należy nadmienić, że owe starania zakończone zostały sukcesem i uzyskaniem pozwoleniem cesarza Ferdynanda I na prowadzenie studiów filozoficznych zgodnie z Ratio Studiorum.

Kluczowym materiałem źródłowym będą dekrety określające program i metody nauczania, spisy profesorów i uczniów, instrukcje dla

20 Akta konwiktu tarnopolskiego z lat 1824-1920, Archiwum Prowincji Południowej Towarzystwa Jezusowego w Krakowie, Rkp nr 1176. 
nauczycieli i wychowawców pracujących w konwikcie, reguły szkolne dla konwiktu w Tarnopolu, programy muzyczne i teatralne, i inne przygotowywane z okazji przyjazdu specjalnych gości. Dokumenty te pozwolą nakreślić struktury organizacyjne i programowe szkoły, skład personalny kadry nauczycielskiej oraz pochodzenie społeczne i terytorialne uczniów konwiktu. Niestety nie ma pełnych danych dotyczących uczniów z lat 1820-1848, jedynie w opracowaniu Maurycego Maciszewskiego znajduje się spis uczniów uczęszczających do gimnazjum w jego pierwszym okresie. Należy nadmienić, że słownik wychowanków konwiktu z lat 1856-1886 został już opracowany i wydany drukiem.

Poza zachowanym w Archiwum materiałem źródłowym rękopiśmiennym i drukowanym, istotne $\mathrm{z}$ punktu widzenia badacza będą również źródła drukowane normatywne. Należy uwzględnić przede wszystkim: ustawy, rozporządzenia i dekrety władz zaborczych dotyczące prowadzenia, funkcjonowania, organizacji szkół w cesarstwie austriackim, m.in. zbiór zasad i przepisów dotyczących przygotowania i ustanowienia szkól, wydany ponownie (po raz trzeci) drukiem w 1820 roku w Wiedniu (Sammlung der Verordnungen und Vorschriften uber die Verfassen und Einrichtung der Gymnasien, Wien 1820), określający m.in. program nauki oraz inne ustawy, rozporządzenia regulujące zasady prowadzenia szkoły. Dokumenty te pozwolą na określenie np. kontekstu politycznego i ideowego oraz warunków, na jakich jezuici mogli wówczas prowadzić działalność edukacyjną. Wydawane wówczas przez władze zaborcze akty prawne dotyczyły również szkół prowadzonych przez zakony. Jezuici musieli $\mathrm{w}$ swoich programach szkolnych uwzględnić zalecenia programowe stawiane władzom gimnazjum oraz korzystać z obowiązujących podręczników do nauki przedmiotów, bowiem „od r. 1820 uczono we wszystkich gimnazyach austryackich, zatem i w tarnopolskim, tych samych przedmiotów i na podstawie tych samych podręczników, wydawanych przez nadworną komisyę naukową"21.

Cennym materiałem źródłowym będą różnego typu wydawnictwa okolicznościowe, jak: Pamiętnik zjazdu konwiktorów tarnopolskich

21 M. Maciszewski, Historya gimnazjum tarnopolskiego. Okres I. 1820-1848, Tarnopol 1896, s. 81. 
z roku 1856-1886 we Lwowie, w dniach 26, 27, 28 i 29 maja 1906; Pamiatka dwudziestopięciolecia chyrowskiego konwiktu 1886-1911 (Chyrów 1911), zawierające nazwiska byłych „Tarnopolczyków”. Ponadto warto odwołać się do dokumentów osobistych (ego-dokumentów) wspomnień uczniów. Materiały wspomnieniowe pozwalają badaczowi być „bliżej ludzi w historii”. Zachowane wspomnienia i pamiętniki będą stanowiły źródło do rekonstrukcji przeszłości szkoły, szczególnie atmosfery i klimatu oraz relacji międzyludzkich - uchwycenia tej mniej formalnej strony życia szkolnego. Przykładem są $W_{\text {spomnienia }}$ Tarnopolskiego Konwiktu, opublikowane w jezuickich „Naszych Wiadomościach", oraz pozostawiony w rękopisie pamiętnik Tarnopolczyka - Wiesława Skarżyńskiego Wspomnienia z pobytu w konwikcie naukowo-wychowawczym w Tarnopolu (1882-1887). „W XX wieku ukazały się dwie cenne źródłowe publikacje, poświęcone braciom Michałowi i Stanisławowi Wysockim (Przemówity stare listy, Kraków 1986) oraz Mycielskim (Gębickie zapiski bistoryczne. Od Anny z Mycielskich Radziwittowej do gen. Stanistawa Rostworowskiego, Gębice 2014). Zawarte w obu wydawnictwach listy ukazują wewnętrzne życie konwiktu, ale też zawierają wiele informacji dotyczących wychowanków innych rodzin ziemiańskich"22.

Znaczącą pomocą w określeniu działalności edukacyjnej konwiktu będą opracowania powstałe wcześniej, a dotyczące bezpośrednio szkoły, jak i działalności zakonu jezuitów tamtego okresu. Należy tu wymienić m.in. pozostawiony w rękopisie pamiętnik Jana Galicza Wygnaniec z Biatej Rusi. Tomik I i II ${ }^{23}$, dzieło Stanisława Załęskiego Jezuici w Polsce, szczególnie tom piąty, cz. 1 i 2 (Kraków 1906); Władysława Chotkowskiego Powrót i powtórne zniesienie zakonu jezuitów w Galicji 1820-1848; oraz Maurycego Maciszewskiego Historia gimnazjum tarnopolskiego: Okres I, 1820-1848 (Tarnopol 1896). Szczególnie ta ostatnia pozycja zasługuje na uwagę i można ją potraktować jako materiał źródłowy, ponieważ autor miał wgląd do niedostępnych współczesnemu badaczowi dokumentów.

22 L. Grzebień, B. Topij-Stempińska, Konwikt szlachecki w Tarnopolu 1856-1886. Stownik wychowanków, dz. cyt., s. 10-11.

23 Jan Galicz jest autorem przepisów prawnych obowiązujących w szkołach prowadzonych przez jezuitów m.in. we Fryburgu, Lwowie i Tarnopolu: W. Krupiński, Jan Galicz SJ. Pedagog jezuicki XIX wieku, Kraków 1996, s. 5. 
Poza materiałem źródłowym przydatne będą również współczesne publikacje odnoszące się bezpośrednio i pośrednio do omawianych kwestii, zarówno monografie innych szkół działających w Galicji, opracowania dotyczące szeroko rozumianego prawa edukacyjnego, historii zakonu tego okresu, autobiografii i biografii wychowanków, nauczycieli i innych osób, które miały wpływ na funkcjonowanie szkoły, jak również opracowania dotyczące historii powszechnej i sytuacji narodu polskiego pod zaborami. W ostatnich latach informacje dotyczące m.in. wychowanków Tarnopola można odnaleźć w internecie - to współczesne „źródło” także należy wziąć pod uwagę. Obecnie istnieje swego rodzaju moda na poszukiwanie korzeni i publikację biografii znanych lub mniej znanych przodków. Może być ono pomocne w ustaleniu losów wychowanków konwiktu w Tarnopolu, szczególnie z jego pierwszego okresu.

\section{Zakończenie}

Przywołane źródła rękopiśmienne, drukowane i wspomniane opracowania nie wyczerpują w pełni podjętego tematu. Należy zaznaczyć, że nie ma pełnych źródeł dotyczących konwiktu tarnopolskiego, a zachowały się tylko nieliczne dokumenty. Niektóre źródła znane są jedynie dzięki opracowaniu Maurycego Maciszewskiego, który korzystał z dokumentacji znajdującej się w szkole tarnopolskiej, a która niestety zaginęła. Krótkie wzmianki o konwikcie tarnopolskim znajdują się w Encyklopedii wiedzy o jezuitach na ziemiach Polski i Litwy, 1564-1995 oraz w artykułach poświęconych szkołom prowadzonym przez jezuitów w Rzeczypospolitej ${ }^{24}$.

Mam nadzieję, że pozostawiony materiał źródłowy pozwoli na odtworzenie działalności edukacyjnej konwiktu tarnopolskiego niewątpliwie zasługującego na przypomnienie, chociażby ze względu na jego znaczenie w kształceniu polskiej młodzieży w dobie zaborów.

24 Np. J. Krysa, Rzut oka na szkoty jezuickie w b. Galicji 1820-1920, „Nasze Wiadomości” 6 (1921-1923), s. 51-58; J. Niemiec, Z dziejów szkolnictwa jezuickiego na ziemiach Rzeczypospolitej w latach 1564-1886, „Resovia Sacra. Studia Teologiczno-Filozoficzne Diecezji Rzeszowskiej 5”1998, s. 263-283. 


\section{BIBLIOGRAFIA}

Akta konwiktu tarnopolskiego z lat 1824-1920, Archiwum Prowincji Południowej Towarzystwa Jezusowego w Krakowie, Rkp nr 1176.

Chotkowski W., Powrót i powtórne zniesienie zakonu jezuitów w Galicji 1820-1848, Kwartalnik Teologiczny,, Warszawa 1904.

Demkowicz A., Wypędzenie jezuitów z Imperium Rosyjskiego na podstawie fragmentów „Wygnańca z Biatej Rusi” Jana Galicza, ,Tematy i Konteksty" 2012, nr 2 (7), s. 54-69.

Encyklopedia wiedzy o jezuitach na ziemiach Polski i Litwy, 1564-1995, opracował L. Grzebień przy współpracy zespołu jezuitów, WAM, Kraków 1996, http://jezuici.krakow.pl/cgi-bin/rjbo?b=enc\&q=TARNOPOL\&f=1 [dostęp: 23.01.2016].

Gębickie zapiski historyczne. Od Anny z Mycielskich Radziwittowej do gen. Stanistawa Rostworowskiego, red. B. Janik, S.J. Rostworowski, Muzeum w Gostyniu, Gębice 2014.

Falkowska J., Dzienniki urzędowe c.k. Rady Szkolnej Krajowej jako źródto do dziejów oświaty w Galicji, w: Badania historyczne w pedagogice. Konteksty źódtowe, red. W. Szulakiewicz, Wydawnictwo Naukowe UMK, Toruń 2015, s. 77-109.

Grzebień L., Topij-Stempińska B., Konwikt szlachecki w Tarnopolu 1856-1886. Stownik wychowanków, Akademia Ignatianum, WAM, Kraków 2016.

Handelsman M., Historyka: zasady metodologii i teorii poznania historycznego, Gebethner i Wolff, Warszawa 1928.

Homplewicz J., Zagadnienia ustawodawstwa szkolnego. Zarys problematyki polskiego prawa szkolnego, Uniwersytet Śląski, Katowice 1973.

Jagusztyn A., Źródto drukowane do dziejów oświaty w Galicji w wybranych bibliotekach $i$ archiwach Polski potudniowo-wschodniej, w: $Z$ dziejów oświaty w Galicji: materiaty z sesji naukowej zorganizowanej w Eańcucie w dniach 23-25 października 1986 roku na temat "Stan i potrzeby badań nad dziejami oświaty w Galicji”, red. A. Meissner, Wydawnictwo WSP, Rzeszów 1989, s. 297-310.

Kościałkowski S., Historyka. Wstęp do studiów historycznych, Polski Uniwersytet na Obczyźnie, Londyn 1954.

Krupiński W., Jan Galicz SJ. Pedagog jezuicki XIX wieku, WAM, Kraków 1996.

Krysa J., Rzut oka na szkoty jezuickie w b. Galicji 1820-1920, „Nasze Wiadomości" 6 (1921-1923), s. 51-58.

Kumor B., Powrót jezuitów do Galicji, „Folia Historica Cracoviensia” 1994, nr 2, s. 75-86.

Kürbis B., Metody źródtoznawcze wczoraj i dzis, „Studia Źródłoznawcze” 1979, nr 24, s. 83-96.

Labuda G., Próba nowej systematyki i nowej interpretacji źródet historycznych, „Studia Źródłoznawcze” 1957, nr 1, s. 3-52. 
Lis T.J., Źródta narracyjne do dziejów Polonii w Bośni i Hercegowinie w okresie austro-wegierskim, „Balcanica Posnaniensia” 2015, nr 22/2, s. 75-89.

Maciszewski M., Historya gimnazjum tarnopolskiego. Okres I. 1820-1848, Z drukarni S. Kossowskiego w Tarnopolu, Tarnopol 1896.

Meissner A., Źródta drukowane do dziejów oświaty, w: Źródta w badaniach naukowych historii edukacji, red. W. Szulakiewicz, Wydawnictwo UMK, Toruń 2003, s. 43-76.

Michalski G., Zakres poszukiwań zródtowych w badaniach historyczno-pedagogicznych stowarzyszen, w: Źródta w badaniach naukowych historii edukacji, red. W. Szulakiewicz, Wydawnictwo UMK, Toruń 2003, s. $145-161$.

Moskalewicz M., Refleksja nad źródtem a problem źródtowości, w: Przez zródto do przesztości: materiaty z II Sesji naukowej doktorantów Wydziatu Historycznego UAM, Poznań, 12-15 kwietnia 2008 roku, red. Iwona Grzelczak-Miłoś, Małgorzata Praczyk, Krzysztof Wiśniewski, Instytut Historii UAM, Poznań 2012, s. 11-27.

Niemiec J., Z dziejów szkolnictwa jezuickiego na ziemiach Rzeczypospolitej w latach 1564-1886, „Resovia Sacra. Studia Teologiczno-Filozoficzne Diecezji Rzeszowskiej 5"1998, s. 263-283.

Pamiętnik zjazdu konwiktorów tarnopolskich z roku 1856-1886 we Lwowie, w dniach 26, 27, 28 i 29 maja 1906, Komitet, Lwów 1906.

Pamiątka dwudziestopięciolecia chyrowskiego konwiktu 1886-1911, Drukiem J. Styfiego w Przemyślu, Chyrów 1911.

Radomski A., Czy jest możliwa bistoryczna interpretacja źródet, https:// www.academia.edu/4167792/Czy_jest_mo\%C5\%BCliwa_historyczna_interpretacja_tekst $\% \mathrm{C} 3 \% \mathrm{~B} 3 \mathrm{w}_{-} \% \mathrm{C} 5 \% \mathrm{BAr} \% \mathrm{C} 3 \% \mathrm{~B} 3 \mathrm{~d} \% \mathrm{C} 5 \% 82 \mathrm{ow}$ ych [dostęp: 4.03.2016].

Sammlung der Verordnungen und Vorschriften uber die Verfassen und Einrichtung der Gymnasien, Wien 1820.

Szulakiewicz W., Ego-dokumenty i ich znaczenie w badaniach naukowych, „Przegląd Badań Edukacyjnych” 2013, nr 16, s. 65-84.

Szulakiewicz W., Korespondencja w badaniach historii edukacji i nauki, w: Badania historyczne w pedagogice. Konteksty źródtowe, red. W. Szulakiewicz, Wydawnictwo UMK, Toruń 2015, s. 2551.

Topolski J., Czy historyk ma dostęp do przesztej rzeczywistości. Problem źródet bistorycznych, w: Historia: o jeden świat za daleko?, wstęp, przekład i opracowanie E. Domańska, Instytut Historii UAM, Poznań 1997, s. 56-70.

Topolski J., Jak się pisze i rozumie historię, Rytm, Warszawa 1998.

Topolski J., Metodologia historii, PWN, Warszawa 1984.

Topolski J., Wprowadzenie do historii, Wydawnictwo Poznańskie, Poznań 2009.

Wojtkowiak Z., Nauki pomocnicze historii najnowszej. Źródtoznawstwo. Źródta Narracyjne, częśc I: Pamiętnik. Tekst literacki, Wydawnictwo Poznańskie, Poznań 2001. 
Wysocki H., Przemówity stare listy, Wydawnictwo Literackie, Kraków 1986.

Załęski S., Jezuici w Polsce, t. V, cz. II, Jezuici w Polsce porozbiorowej 1820-1905, Drukiem i nakładem W.L. Anczyca i sp., Kraków 1906.

\section{ADRES DO KORESPONDENCJI}

Dr Beata Topij-Stempińska

Akademia Ignatianum w Krakowie,

Wydział Pedagogiczny, Instytut Nauk o Wychowaniu

Katedra Historii Oświaty i Wychowania

btopii@ignatianum.edu.pl 